\title{
Reversible in vivo cellular changes occur during desiccation and recovery: Desiccation tolerance of the resurrection filmy fern Hymenophyllum dentatum Cav.
}

\section{Cambios celulares reversibles observados in vivo durante la desecación y recuperación: Tolerancia a la desecación del helecho película de resurrección Hymenophyllum dentatum Cav.}

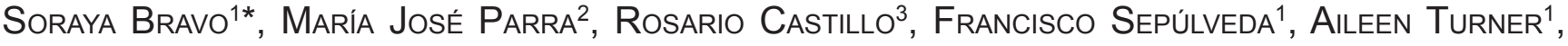 \\ Ariana Bertín ${ }^{1}$, Germán Osorio ${ }^{4}$, Joanna Tereszczuk ${ }^{4}$, Carola Bruna $^{5}$ \& Rodrigo Hasbún ${ }^{6}$. \\ ${ }^{1}$ Centro de Biología Vegetal, Facultad de Ciencias Biológicas, Universidad Andrés Bello, Autopista Concepción-Talcahuano, \\ Chile. \\ ${ }^{2}$ Facultad de Ciencias, Universidad San Sebastián, Lientur 1457, Concepción, Chile. \\ ${ }^{3}$ Departamento de Análisis Instrumental, Facultad de Farmacia, Universidad de Concepción. Casilla 160-C, Concepción, \\ Chile. \\ ${ }^{4}$ Centro de Microscopía Avanzada CMA Biobío, Barrio Universitario, Ennio Vivaldi, piso 2, Concepción, Chile. \\ ${ }^{5}$ Departamento de Bioquímica y Biología Molecular, Facultad de Ciencias Biológicas, Universidad de Concepción, Casilla160-C, \\ Concepción, Chile. \\ ${ }^{6}$ Departamento de Silvicultura, Laboratorio de Epigenética de Plantas, Facultad de Ciencias Forestales, Universidad de \\ Concepción, Victoria 631, Concepción, Chile. \\ *soraya.bravo@unab.cl
}

\begin{abstract}
The present work explores in vivo physiological, morphological and chemical features during full hydration, desiccation and rehydration of the filmy fern Hymenophyllum dentatum with two main objectives: 1) to get further insight about the mechanisms underlying its desiccation tolerance, and 2) to understand how this plant manages mechanical stress induced by water loss and recovery. With these purposes, physiological (relative water content and $\mathrm{F}_{\mathrm{v}} / \mathrm{F}_{\mathrm{m}}$ chlorophyll fluorescence parameter), morphological (Confocal Laser Scanning Microscopy and 3D reconstruction) and chemical (FTIR microspectroscopy) data were obtained and compared between fully hydrated, desiccated and rehydrated tissues of H. dentatum. Remarkable changes in cell architecture and chemical composition were observed in vivo in desiccated leaves. Cells were smaller, showed a collapsed general appearance, and were delimitated by apparently folded cell walls. Marked changes in chloroplasts location and decrease in the number of active chloroplasts were also evidenced. Chemical experiments showed that changes in the secondary structure of proteins and in the polysaccharide composition of the cell wall occur in desiccated cells. All changes were rapidly reversed upon rehydration. This study shows that $H$. dentatum presents an extreme case of desiccation tolerance, able to withdraw severe, rapid and consecutive dehydration/rehydration induced stress by the function of constitutive systems of protection and reparation, in which cell wall folding plays a relevant role as a protective system against mechanical and oxidative stress. Besides, H. dentatum is proposed as an excellent plant model for the study of dissection tolerance such as one cell layer fern, auto-fluorescence of cellular compartments, and simple long term storage under laboratory conditions, among others.
\end{abstract}

KEYwORDs: Hymenophyllum, desiccation tolerance, confocal 3D microscopy, FT-IR microspectroscopy, rapid dehydration /rehydration.

\section{RESUMEN}

El presente trabajo muestra una exploración in vivo de los rasgos fisiológicos, morfológicos y químicos que caracterizan a los estados de hidratación completa, desecación y rehidratación del helecho película Hymenophyllum dentatum, que persigue 2 objetivos principales: 1) Adquirir conocimientos sobre los mecanismos que subyacen a la tolerancia a la desecación, y 2) entender cómo estas plantas manejan el estrés mecánico inducido por la pérdida y recuperación de agua. Con estos propósitos se obtuvo datos fisiológicos (contenido relativo de agua y parámetro de fluorescencia de clorofila $\mathrm{Fv} / \mathrm{Fm}$ ), 
In vivo cellular changes during desiccation of Hymenophyllum dentatum: BRAVO, S. ET AL.

morfológicos (microscopía confocal de escaneo laser en 3 D) y químicos (microespectroscopía FT-IR), en los tejidos de $H$. dentatum en los estados completamente hidratado, desecado y rehidratado. Notorios cambios en la arquitectura celular y la composición química fueron observados in vivo en las hojas desecadas. Las células eran de menos tamaño, presentaron una apariencia general colapsada, y delimitadas por una pared celular con apariencia plegada. También se evidenciaron marcados cambios en la localización y una disminución en el número de cloroplastos activos durante la desecación. Los ensayos químicos mostraron que en las células en desecación ocurren cambios en la estructura secundaria de una proteína citoplasmática muy abundante y en los polisacáridos que componen la pared celular. Todos estos cambios revierten al estado inicial tras la rehidratación de los tejidos. Este estudio muestra que $H$. dentatum es un caso extremo de tolerancia a la desecación, capaz de sobreponerse tras el estrés inducido por ciclos de alternancia entre desecación y rehidratación, mediante el funcionamiento de sistemas constitutivos de protección y reparación, entre los cuales el plegamiento de la pared celular parece jugar un rol clave como protector contra el daño mecánico y el estrés oxidativo. Además, $H$. dentatum es propuesto como una excelente planta modelo para el estudio de la tolerancia a la desecación porque posee características como tener hojas constituidas por una sola capa de células, poseer estructuras internas auto-fluorescentes, resistencia en condiciones simples de almacenamiento en el laboratorio, entre otras.

Palabras clave: Hymenophyllum, tolerancia a la desecación, microscopía confocal 3D, microespetroscopía FT-IR, desecación y rehidratación rápida.

\section{INTRODUCTION}

Vegetative tissues of land plants have different levels of tolerance to water deficiency. While some plants are extremely sensitive, showing signs of damage after $10 \%$ of water loss, others survive extreme loss of water or desiccation (90\% of water loss or more) (Gechev et al. 2012). To be considered a desiccation tolerant plant, an organism must be able to protect the cellular integrity of vegetative tissue in the desiccated state and resume its normal metabolism upon rehydration (Bewley 1979). Desiccation tolerant plants can be classified in two main categories: fully desiccation tolerant plants that can withstand the total loss of free protoplasmic water at any rate, and modified desiccation tolerant plants that can only survive such stress if water loss is slow. Plant complexity appears to influence which category a plant belongs to (Oliver et al. 1997). Fully desiccation tolerance has been associated with a poikilohydric strategy exemplified by bryophytes, while modified desiccation is associated with vascular plants (Proctor \& Tuba 2002). In general, fully desiccation tolerant plants are less complex and may rely more on overall cellular protection and repair to overcome sudden changes in water content (Oliver et al. 2005). The survival of vascular plants instead, depends on mechanisms of cellular protection that are induced during dehydration and thus, require a certain amount of time to become established in leaf tissues (Rascio \& La Rocca 2005). Proteome differential expression and sugar accumulation are well-known inducible desiccation mechanism (Garces Cea et al. 2014). These plants, also known as resurrection plants, are members of pteridophytes and angiosperms (Rascio \& La Rocca 2005).

Two main groups of resurrection plants are distinguished by their capacity to degrade or retain chlorophyll during desiccation. Homoiochlorophyllous resurrection plants retain chlorophyll and thylakoid structures during dehydration (Rodriguez et al. 2010). Poikilochlorophyllous resurrection plants degrade their chlorophyll and resynthesize it after rehydration. Homoiochlorophyllous are subjected to a greater risk of photo-oxidative and metabolic damage occurring because active photosystems can be uncoupled from metabolic dissipation mechanisms, resulting in oxidative damage (Moore et al. 2009), which is minimized by additional morphological and biochemical mechanisms such as leaf folding to reduce absorbed radiation or/and accumulation of anthocyanins and other phenolic compounds to protect against solar radiation (Farrant \& Moore 2011).

During desiccation, the progressive decrease in water content imposes considerable mechanical stress on plant cell architecture and exposes the macromolecules to a risk of dehydration and inactivation (Gechev et al. 2012). Resurrection plants use two different approaches to minimize this stress: 1) water replacement, where cells maintain their original volume and became packed with vacuoles filled with non-aqueous matter and 2) reduction in cellular volume by extensive cell wall folding, which should reduce tensions on structures enclosed by the wall (Willigen et al. 2004). The mechanisms by which the cell walls of desiccation tolerant species manage to withstand the strain caused by massive loss of cellular water (and volume) and changes in mechanical properties of wet versus dry cell walls remain unresolved (Moore et al. 2006, Layton et al. 2010).

Hymenophyllum dentatum Cav. belongs to the Hymenophyllaceae family, phyllum Monilophyta, one of the most primitive families Pteridophyta (Pryer et al. 1995), characterized by leaves conformed by typically only one cell thick (hence the name filmy ferns) and the lack of stomata. Filmy ferns provide a rare instance of a coherent vascular plant family committed to a poikilohydric mode of life (Proctor 2012). Hymenophyllum genus contains around 250 species distributed all over the world, preferentially in tropical and temperate humid forests. These ferns live as 
epiphytes over the trunk of trees (Hennequin 2004), in a well described vertical distribution pattern (Parra et al. 2009). $H$. dentatum is an endemic species of the temperate rain forests of south of Chile and Argentina (Larsen et al. 2013), and as other filmy ferns (Proctor 2012), has been recently reported as desiccation tolerant plant (Saldaña et al. 2013). Although filmy ferns are classified as modified tolerant, since they are vascular plants, based on ecophysiological data, Hymenophyllaceae have been recently described as an rare example of an evolutionary shift of adaptive strategy from that typical for vascular plants to that of poikilohydry (Garces Cea et al. 2014). It has been suggested that desiccation tolerance in $H$. dentatum relies on a constitutive mechanism of cellular protection, displaying a poikilohydric homoiochlorophyllous pattern. It has been demonstrated that $H$. dentatum possesses constitutively high levels of sucrose, its proteome remain largely unchanged during desiccation and rehydration and that the speed at which desiccation takes place precludes the induction of protective systems (Garces Cea et al. 2014). Nevertheless, the mechanisms of this plant to manage mechanical stress are barely known.

This study explores in vivo physiological, morphological and chemical features during full hydration, desiccation and rehydration with two main purposes: 1 ) to get further insight about the mechanisms underlying the resurrection of $H$. dentatum, and 2) to understand how this filmy fern manages mechanical stress induced by rapid and extreme water loss and recovery. The cellular responses detected by different experimental approaches showed that $H$. dentatum has an extraordinary adaptive capacity to minimize deleterious effects of consecutive changes in environmental water availability. The understanding of the strategies used by this vascular plant to tolerate extreme water limitation at molecular and cellular level is not only a contribution to the biology of this species. This report contributes to the understanding of the mechanisms that allows plants to make an improved use of water and be resistant to water deficit, which can be applied with biotechnological purposes.

\section{MATERIALS AND METHODS}

Plant material. Fully expanded fronds of $H$. dentatum were collected from their natural habitat growing in the trunks of second-growth forest stands in the southern temperate rainforest of Chile, Región de Los Lagos, in the Cordillera de Quillaipe, Katalapi Park ( $41^{\circ} 31^{\prime}$ S- $\left.72^{\circ} 45^{\prime} \mathrm{W}\right)$. This site has been extensively characterized previously (Saldaña et al. 2013, Garces Cea et al. 2014). Samples were harvested during winter of 2013. Leaves were collected and transported in full hydration conditions, and then they were acclimated by being kept in a growth chamber at $20^{\circ} \mathrm{C}$, immersed in water under near natural light conditions with photoperiod $16 \mathrm{~h}$ of light / $8 \mathrm{~h}$ of darkness, during at least
10 days. Leaves were able to live in these conditions for more than a year without manifesting any signs of damage, only requiring weekly changes of the water. For desiccation, two fronds were placed in dry open Petri dishes and were allowed to dry for $18 \mathrm{~h}$ in dark at room temperature. For rehydration, $30 \mathrm{ml}$ of water was placed in the Petri dishes and leaves were maintained immersed for $2 \mathrm{~h}$. The same steps of desiccation and rehydration were repeated 3 times for testing the ability of leaves that have been stored in water for a year, to tolerate consecutive cycles of dehydration and recovery (Fig. 1.)

Physiological measurements. Relative Water Content (RWC) of $H$. dentatum fronds was determined gravimetrically by weighing them in full hydration condition and then, during desiccation and rehydration the weight was registered every $5 \mathrm{~min}$ and every 10 or $30 \mathrm{~min}$
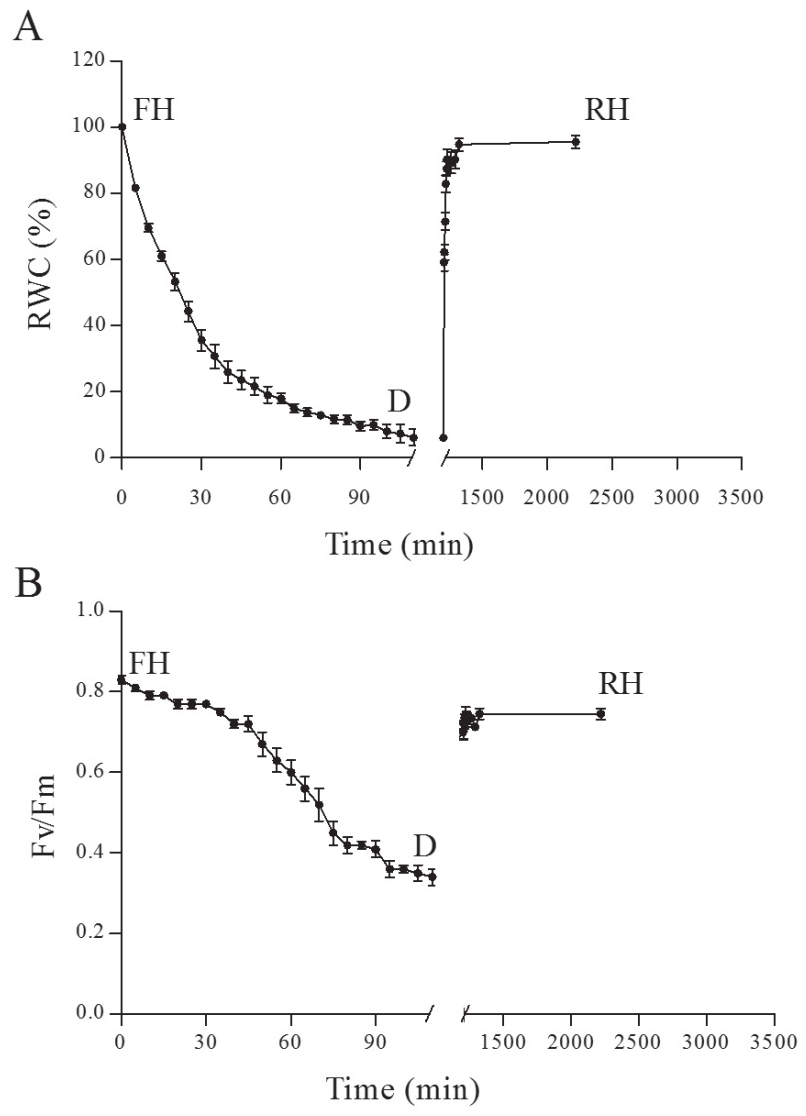

FIgURE 1. Physiological parameters. A. Relative water content (RWC) curve. B. Fv/Fm rates of $H$. dentatum representative of three independent experiments. Means \pm s.d. $n=12$. FH: Full hydration. D: Dehydration. RH: Rehydration.

Figura 1. Parámetros fisiológicos. A. Curva de contenido relativo de agua (CRA). B. Tasas de Fv/Fm de H. dentatum representativas de tres experimentos independientes. Promedio \pm s.d. $n=12$. FH: Hidratación completa. D: Desecación. RH: Rehidratación. 
for longer registration of rehydration. The weight of full hydrated leaves was considered to be the $100 \%$ of RWC. Twelve experimental replicates were essayed. Chlorophyll fluorescence parameter $\mathrm{Fv} / \mathrm{Fm}$ was registered with a modulated chlorophyll fluorimeter (FMS1, Hansatech Ltd., King's Lynn, UK) over the same fronds used for RWC determination. These measurement were made during spring of 2013.

Morphological measurements. A confocal microscope LSM780 (Axio Observer.Z1, Carl Zeiss, Germany) with ZEN 2011 software v8.0, SP 2 (Carl Zeiss, Germany) and 40x objective (EC Plan-NeoFluar, oil immersion, NA 1.4) was used to acquire images of sections of 3 fronds in each condition (full hydrated, desiccated and rehydrated) without any pretreatment. The images were acquired in 3D stacks with Z-steps of $1 \mu \mathrm{m}$ and 43-106 focal planes. The channel corresponding to chlorophyll fluorescence was acquired using excitation wavelength of $633 \mathrm{~nm}$ (DPSS laser) and detecting the emission in the range $638-747 \mathrm{~nm}$. The channel representing other types of auto-fluorescence was acquired with $488 \mathrm{~nm}$ excitation laser (Argon laser) and the emission was detected in the range of 490-560 nm. Additionally, transmitted light with differential interference contrast (DIC) was acquired with a LSM T-PMT detector. The images were processed with Imaris software (Bitplane AG, Zurich, Switzerland). From each image five central cells were selected and manually segmented using the focal plane image of transmitted light as reference. Although the whole cell thickness was impossible to measure, as the transmitted light was out of focus for most of the volume, the plane size and form of the cells were successfully analyzed. The values of cell areas and bounding box dimensions (i.e. length and width) were collected. To analyze the chloroplasts distribution three random cells were selected out of the five previous images. In each cell the chloroplasts were independently segmented using automatic intensity threshold and smoothing parameter of $500 \mathrm{~nm}$. Chloroplasts of each cell were highlighted with different colors. For their number calculation, manual enumeration with Measurement Point tool was used, guided by 3D image projections in various directions. The number of chloroplasts and total fluorescence intensity were recollected for each cell. Statistical comparison was made using unpaired $t$-test $(\mathrm{P}=0.005)$.

Chemical measurements. Sections of 3 fronds in each hydration condition were analyzed by FT-IR microspectroscopy using a Spotlight 400 FT-IR Imaging System (Perkin Elmer, Waltham, Massachusetts, USA) in transmission mode. Five spectra were collected from each of the five cells selected in each leave section, avoiding the raquis and the borders of the leaves. Spectra were recorded between 4,000 and $648 \mathrm{~cm}^{-1}$ with spectral resolution of 8 $\mathrm{cm}^{-1}$ and 32 scans per point. Each spectrum corresponds to an area of $6.25 \times 6.25 \mu \mathrm{m}^{2}$. Spectra were normalized and base line was corrected between 1500 and $1648 \mathrm{~cm}^{-1}$. Second derivative was calculated with 25 point using Pirouette 4.5 software (Infometrix Inc., Bothel, Washington, USA). For comparing the spectra obtained from the fronds on the three hydration states Principal Component Analysis (PCA) multivariate technique was applied, using the whole spectral range (4000-648 $\mathrm{cm}^{-1}$ ). For further comparison of desiccated cells with both full hydrated and rehydrated cells a reduced PCA was made using the spectral range of $1800-648 \mathrm{~cm}^{-1}$. PCAs were made with Pirouette 4.5 software (Infometrix Inc., Bothel, Washington, USA).

\section{RESULTS}

Physiological parameters DURing FUll hydration, DESICCATION, AND REHYDRATION

Plant Relative WATER CONTENT (RWC). RWC time curse in Figure 1A shows the rate of water loss during desiccation and rehydration. After 60 min upon desiccation RWC of the dry fronds was near $20 \%$. After $90 \mathrm{~min}$, RWC of desiccated fronds was $10 \%$. After $18 \mathrm{~h}$ of dehydration, fronds recovered $80 \%$ of RWC of fully hydrated fronds in $20 \mathrm{~min}$ after rehydration. The RWC recovery reached approximately $95 \%$ of the fully hydrated fronds. $H$. dentatum fronds that have been stored in water for more than a year were able to tolerate 3 continuous cycles of desiccation and rehydration presenting the same trend than in the one cycle experiments showed in Figure 1A, except by a moderated decrease on RWC recovery in the desiccated fronds after the second desiccation cycle.

Chlorophyll Fluorescence. Chlorophyll fluorescence provides a rapid and non-invasive mean of exploring aspects of the behavior of the photosynthetic system during and following environmental stress (Lichtenthaler 1988, Bolha-Nordenkampf \& Öquist 1993, Schreiber \& Bilger 1993, Schreiber et al. 1995). The measure of the maximum efficiency of photosystem II Fv/Fm has been widely used to study desiccation tolerance in plants. The time curse of $\mathrm{Fv} / \mathrm{Fm}$ presented in Figure 1B shows that after $60 \mathrm{~min}$ upon desiccation, when the leaves reached $20 \%$ RWC, a considerable decrease Fv/Fm was observed. At 90 min upon desiccation Fv/Fm was the half of the unstressed condition. The values decreased to its minimum level at 110 min upon desiccation.

The recovery of Fv/Fm is almost instant upon rehydration. Nevertheless, it does not reach the initial value of the unstressed conditions reaching an approximately $90 \%$ of the full hydrated response. 
MORPHOLOGICAL PARAMETERS DURING FULL HYDRATION, DESICCATION, AND REHYDRATION

Morphology OF FRONDS. Hydrated fronds were light green and expanded (Figure 2A). Desiccated leaves (Figure 2B) suffered a dramatic transformation. Fronds and pinnae turn dark green and tightly curled inward. The frond surface area strongly decreased to about one third of the full hydrated state. Rehydrated fronts (Figure 2C) were expanded and they recovered completely the leaf surface area, but the green color was not as light as in full hydrated fronds.
MoRPhology OF CELLS. In vivo characterization of the cells in full hydrated, desiccated and rehydrated state was made by Confocal Laser Scanning Microscopy (CLSM). CLSM is a high resolution microscopic technique which can also reconstruct images of the internal 3D anatomy of tissues and cells by capturing the fluorescence from fluorochromes within the tissues and cells (Omasa et al. 2009). As the fronds of $H$. dentatum are composed by only one cell layer and possess natural fluorescence, the in vivo observation of the full hydrated, desiccated and rehydrated tissues was
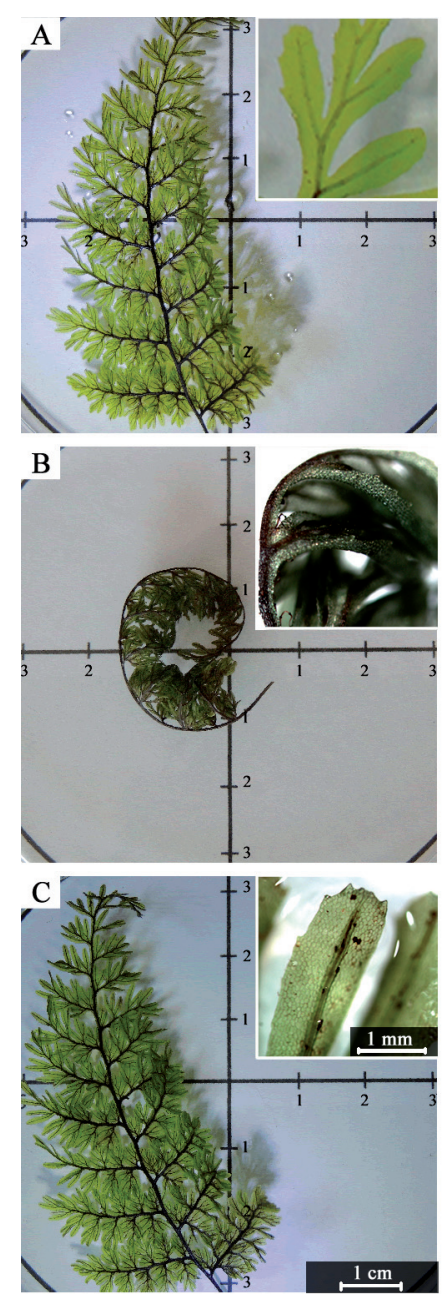
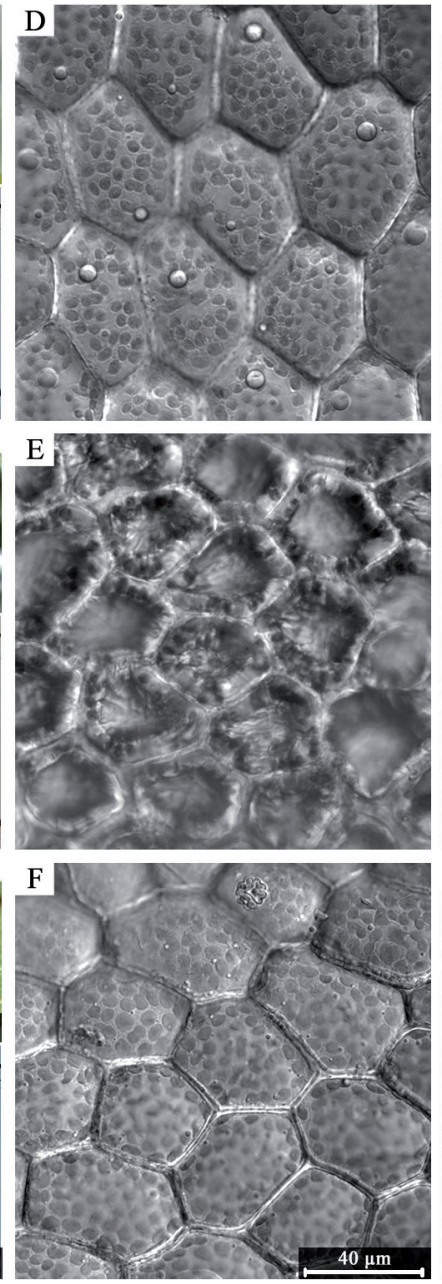
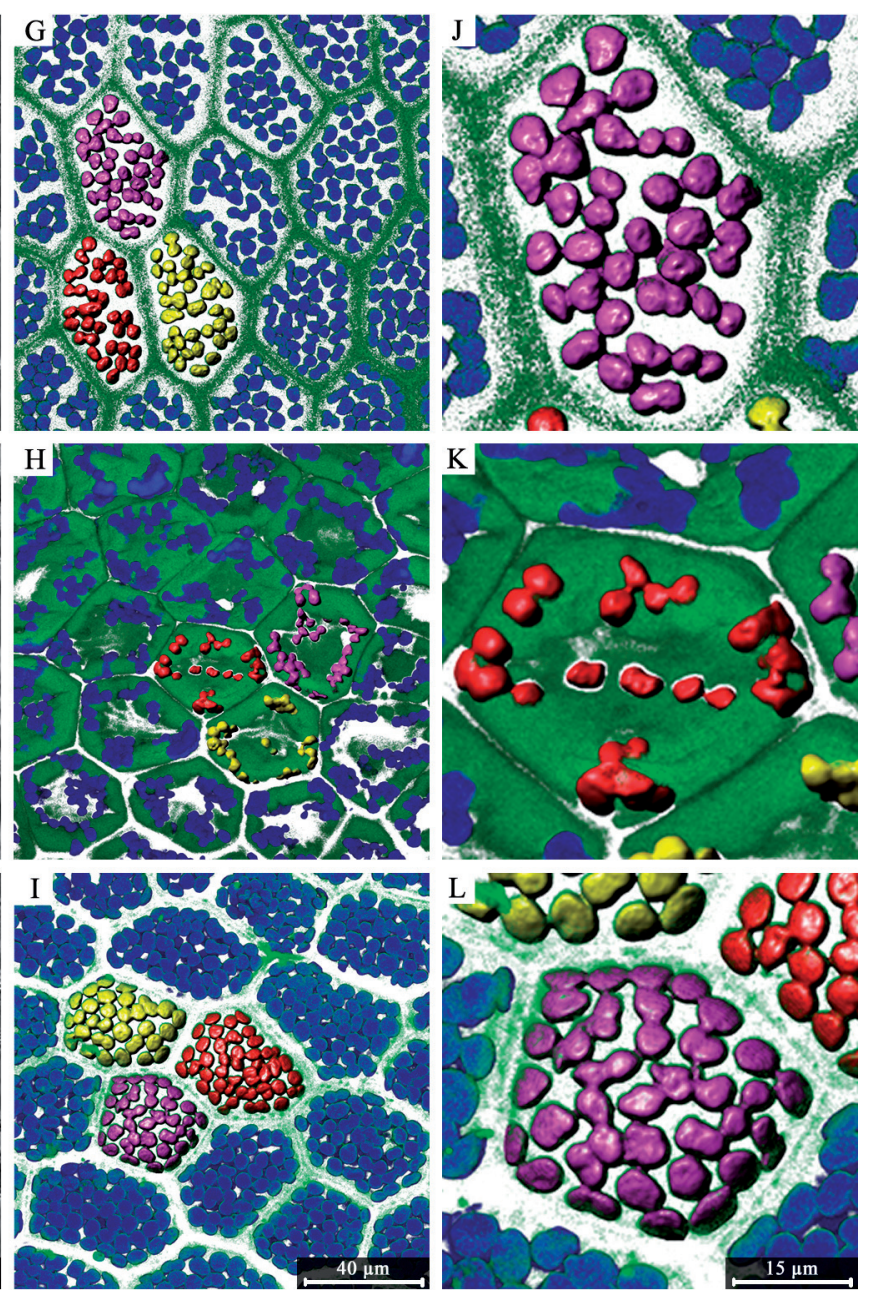

Figure 2. Morphological changes. A, B and $\mathrm{C}$ show representative leaves in full hydration, desiccation and rehydration respectively. Boxes in the right upper corner show a detail of the pinnae. D, E and F show images of differential interference contrast (DIC) obtained by transmitted light, corresponding to full hydrated, desiccated and rehydrated cells, respectively. G, H and I show 3D confocal images of full hydrated, desiccated and rehydrated cells, respectively. A segmentation of chloroplasts was made. Colors of chloroplasts were used only to highlight them. J, K and L show details of one cell selected out the previous figures.

Figura 2.Cambios morfológicos. A, B y C muestran frondes representativas en condición de hidratación completa, desecación y rehidratación, respectivamente. El rectángulo superior derecho muestra las pinna en detalle. D, E y F muestran imágenes de contraste de interferencia diferencial (CID) obtenidas por luz transmitida, correspondiendo a los estados de hidratación completa desecación y rehidratación, respectivamente. G, H e I, muestran imágenes confocales en $3 \mathrm{D}$ de las células en los estados de hidratación completa desecación y rehidratación, respectivamente. J, K y L presenta detalles de una célula seleccionada de la figura anterior, en la que se muestra la segmentación de cloroplastos. Los colores se usan solamente para destacar los límites de cada uno de ellos. 
possible. Full hydrated tissue (Figure 2D) was composed by polygonal cells delimited by straight cell walls. Desiccated tissue was drastically different (Figure 2E), cells were apparently smaller, delimited by folded cell walls, having a collapsed general appearance. Rehydrated cells (Figure 2F) recovered their unstressed appearance almost completely. Chloroplasts were homogenously distributed over the cell surface in full hydrated tissue (Figure $2 \mathrm{G}$ ). In desiccated cells (Figure $2 \mathrm{H}$ ), an apparent decrease in the number of chloroplasts was observed. The chloroplasts were located at the borders of the collapsed cells. Rehydrated cells recovered the number and distribution pattern of chloroplasts of unstressed condition (Figure 2I). No important desiccation or rehydration induced changes were observed in the irregular rounded shape and the size (4-7 $\mu \mathrm{m}$ of diameter) of the chloroplasts (Figures 2J, K and L). Shape and size are consistent with the reported for other desiccation tolerant plants (Proctor et al. 2007).

To further investigate the cellular changes described previously, 3D reconstruction images were projected in various directions. Desiccated cells (Figure 3A) were highly concave and their cell walls presented a wrinkled texture. Besides, differences in cell size between full hydrated, desiccated and rehydrated tissues were confirmed (Figure $3 \mathrm{~B})$. Although the width of the cells remained unchanged, in desiccated tissue the length and area were significantly lower than full hydrated or rehydrated cells, indicating that desiccation reduce the cellular size. Rehydrated cells almost completely recovered their cell volume.

Using 3D reconstruction the apparent change in the number of chloroplasts during desiccation was also quantified (Figure 3C). The mean number of detected chloroplasts in full hydrated tissues was 47 per cell, which is consistent with the number reported for other plants (Ellis \& Leech 1985). The number of chloroplast per cell decreased to 27 in desiccated tissues and recovered to 40 in rehydrated tissues. As the detection of chloroplasts depends on the intensity of their fluorescence (Figure 3D), this results indicate that during desiccation over a $40 \%$ of the population of chloroplasts are inactive. The fast recovery of their number and location during rehydration indicates that they were maintained intact upon desiccation.

\section{Chemical Changes DURING FUll hydRATION, DESICCATION AND REHYDRATION}

IN VIVO DETECTION OF THE CHEMICAL COMPOSITION OF THE CELLS Chemical changes in the cells induced by desiccation and rehydration were analyzed by Fourier transform infrared microspectroscopy (FT-IR). FT-IR is a non-destructive analytical technique that allows reliable, direct and fast determination of several properties without any sample pretreatment (Wang 2012). It has been used for the study of intact cells, tissues and whole organisms (Ami et al. 2010). The entire FT-IR spectra of an organic compound provide
A

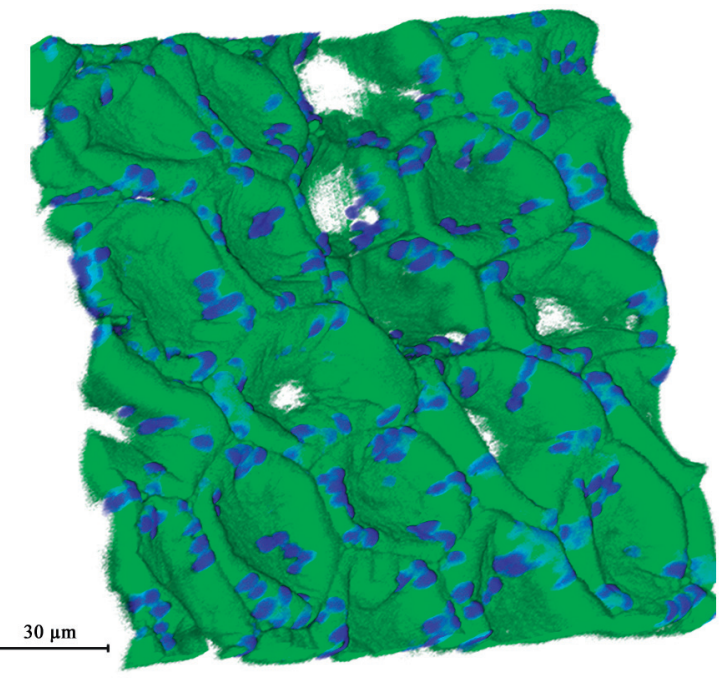

B
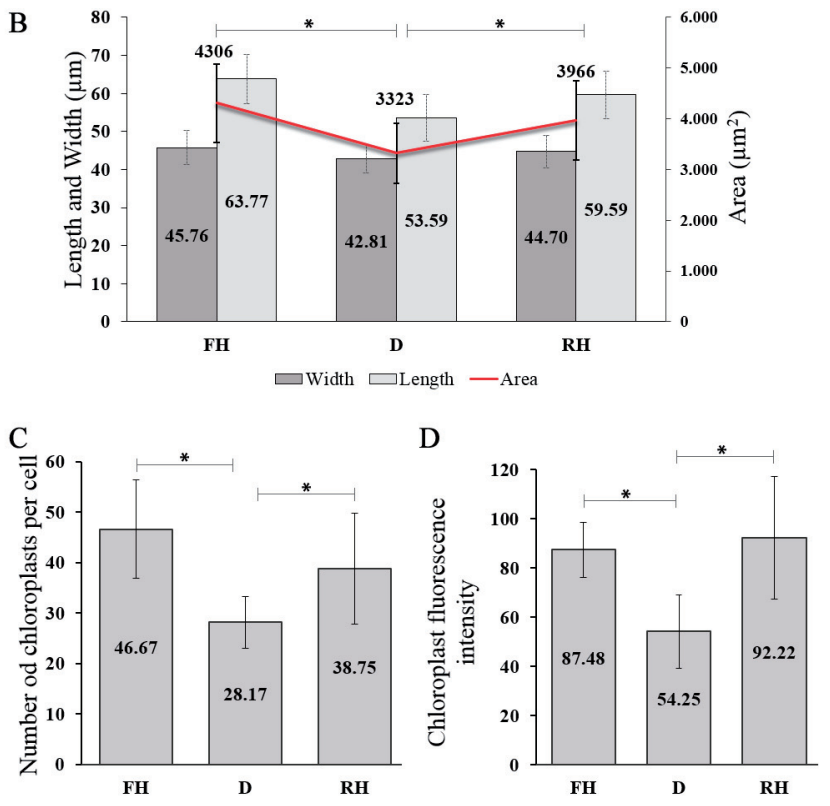

Figure 3. Cell folding and chloroplasts inactivation. A shows one representative position of the $3 \mathrm{D}$ image projection of desiccated fronds. B illustrates the changes in cellular size during desiccation and rehydration. Statistical significance $(\mathrm{P}=0.05)$ of area is indicated. C and D illustrates the changes in chloroplasts number and fluorescence intensities, respectively, occurring in full hydration, desiccation and rehydration conditions. FH: Full hydration. D: Dehydration. RH: Rehydration.

Figura 3. Plegamiento celular e inactivación de cloroplastos. A muestra una imagen de una posición representativa de la proyección en $3 \mathrm{D}$ de las frondes desecadas. B ilustra los cambios en el tamaño celular durante la desecación y rehidratación. La diferencia estadística $(\mathrm{P}=0,005)$ de áreas es indicada en la figura. $\mathrm{C}$ y D ilustran los cambios en el número de cloroplastos y en las intensidades de fluorescencia que ocurren en las condiciones de hidratación completa, desecación y rehidratación. FH: Hidratación completa. D: Desecación. RH: Rehidratación. 
a unique fingerprint, which can be readily distinguished from FT-IR absorption pattern of other compounds (Wang 2012). The application of FT-IR to the study of biological systems is based on the knowledge of the band assignment of the infrared absorption due to the functional groups of the most important biomolecules (Ami et al. 2011). As the leaves of $H$. dentatum are made of a single cell layer and microspectroscopy allows the selection of specific areas for acquiring the spectra, the FT-IR spectra obtained represent the chemical composition of whole cells. Figure 4A shows the mean spectra of five cells in each hydration condition. The most important band peaks, their assignments and the differences between full hydrated, desiccated and rehydrated cells are enlisted in Table I.

TABLE I. FT-IR. microspectroscopy results. The assignments of main band peaks of the spectra obtained from full hydrated, desiccated and rehydrated cells are enlisted. Changes in spectra were indicated in Results item.

TABLA I. Resultados del análisis por microespectroscopía FT-IR. Identificación de los principales picos en los espectros obtenidos en células en estado de hidratación completa, desecación y rehidratación. Los cambios en los espectros se comentan en la columna resultados.

\begin{tabular}{|c|c|c|}
\hline $\begin{array}{l}\text { WAVENUMBER } \\
\left(\mathrm{cm}^{-1}\right)\end{array}$ & Literature BAND Assignment & RESUlts \\
\hline 3617 & $\begin{array}{l}\text { OH Stretching vibrations. Correspond to weakly bonded OH groups of water } \\
\text { (Noguchi 2008). In hydrated tissue this spectral range is dominated by water. } \\
\text { In desiccated state, these bands are originated from carbohydrates and proteins } \\
\text { (Wolkers \& Hoekstra 2003). This spectral range informs about the water } \\
\text { content of the samples (Konwar \& Baruah 2011, Ivanova \& Singh 2003). }\end{array}$ & $\begin{array}{l}\text { Shifted to } 3562 \mathrm{~cm}^{-1} \text { in desiccated } \\
\text { and rehydrated cells. }\end{array}$ \\
\hline 2923 and 2856 & $\begin{array}{l}\mathrm{CH}_{2} \text { stretching vibrations originated from lipids. Correspond to asymmetric } \\
\text { and symmetric stretching respectively (Wolkers \& Hoekstra 2003). }\end{array}$ & $\begin{array}{l}\text { The band at } 2923 \mathrm{~cm}^{-1} \text { has higher } \\
\text { intensity in desiccated cells. }\end{array}$ \\
\hline $2500-2000$ & & Noise. \\
\hline 1732 & $\begin{array}{l}\mathrm{C}=\mathrm{O} \text { stretching vibrations. Correspond to membrane lipids and pectin of the } \\
\text { cell wall (Mazurek et al. 2013, Yang \& Yen 2002). }\end{array}$ & $\begin{array}{l}\text { Presented equally in full hydrated, } \\
\text { desiccated and rehydrated cells. }\end{array}$ \\
\hline 1640 & $\begin{array}{l}\mathrm{C}=\mathrm{O} \text { stretching vibrations with minor contribution of the out of phase } \mathrm{C}-\mathrm{N} \\
\text { stretching vibration. Correspond to the Amide I group of proteins (Tolleter } \\
\text { et al. 2007) and informs about changes in their secondary structure (Barth \& } \\
\text { Zscherp 2002). }\end{array}$ & $\begin{array}{l}\text { Shifted to } 1614 \mathrm{~cm}^{-1} \text { in desiccated } \\
\text { and rehydrated cells. }\end{array}$ \\
\hline 1526 & $\begin{array}{l}\text { N-H in plane bending and C-N stretching vibration. Correspond to the Amide } \\
\text { II of proteins, and has been shown to be insensitive to conformational changes } \\
\text { (Wolkers \& Hoekstra 2003, Mazurek et al. 2013, Wang 2012). }\end{array}$ & $\begin{array}{l}\text { Presented equally in full hydrated, } \\
\text { desiccated and rehydrated cells. }\end{array}$ \\
\hline 1445 & $\begin{array}{l}\text { O-H and C-H stretching vibrations. Correspond to cell wall polysaccharides } \\
\text { (McCann et al. 1992, Kačuráková et al. 2000, Stehfest et al. 2005, Wang 2012, } \\
\text { Mazurek et al. 2013). }\end{array}$ & $\begin{array}{l}\text { Presented equally in full hydrated, } \\
\text { desiccated and rehydrated cells. }\end{array}$ \\
\hline 1368 & $\begin{array}{l}\text { C-H stretching vibrations. Correspond to cell wall polysaccharides (McCann } \\
\text { et al. 1992, Kačuráková et al. 2000, Stehfest et al. 2005, Wang 2012, Mazurek } \\
\text { et al. 2013). }\end{array}$ & $\begin{array}{l}\text { Presented equally in full hydrated, } \\
\text { desiccated and rehydrated cells. }\end{array}$ \\
\hline 1272 & $\begin{array}{l}\text { N-H bending and C-N stretching vibrations of Amide III (Barth \& Zscherp } \\
\text { 2002, Yang \& Yen 2002, Mazurek et al. 2013). }\end{array}$ & $\begin{array}{l}\text { Presented equally in full hydrated, } \\
\text { desiccated and rehydrated cells. }\end{array}$ \\
\hline 1144 & $\begin{array}{l}\text { C-O-C stretching vibrations overlapped with C-OH stretching vibrations. } \\
\text { Correspond to cell wall polysaccharides, most likely pectin or arabinan } \\
\text { (Kačuráková et al. 2000, Wang 2012). }\end{array}$ & $\begin{array}{l}\text { Presented equally in full hydrated, } \\
\text { desiccated and rehydrated cells. }\end{array}$ \\
\hline 1000 & $\begin{array}{l}\text { C-O-C stretching vibrations. Correspond to cell wall polysaccharides, likely } \\
\text { pectin (McCann et al. 1992, Stehfest et al. 2005, Mazurek et al. 2013). }\end{array}$ & $\begin{array}{l}\text { Lower intensity in desiccated and } \\
\text { rehydrated cells. }\end{array}$ \\
\hline 802 & Not reported. & Higher intensity in rehydrated cells. \\
\hline 710 & $\mathrm{CH}_{3}$ symmetrical bending vibrations (Zeier \& Schreiber 1999). & $\begin{array}{l}\text { Presented exclusively in desiccated } \\
\text { cells. }\end{array}$ \\
\hline under 700 & & Noise. \\
\hline
\end{tabular}


Principal Component Analysis (PCA) multivariate technique was applied to analyze the spectral data (Figure 4B). The PCA plot, accounting for $86 \%$ of the total variation with $\mathrm{PC} 1$ and $\mathrm{PC} 2$ accounting for 75 and $11 \%$ of the variation, respectively, shows that rehydrated cells were in an intermediate condition between full hydration and desiccation. Further analysis (Figure 4C) show that the main differences between the desiccated tissue and the full hydrated and rehydrated tissue in terms of the chemical composition of the cells are related to changes in the secondary structure of proteins (Amide I band) and cell wall polysaccharides.

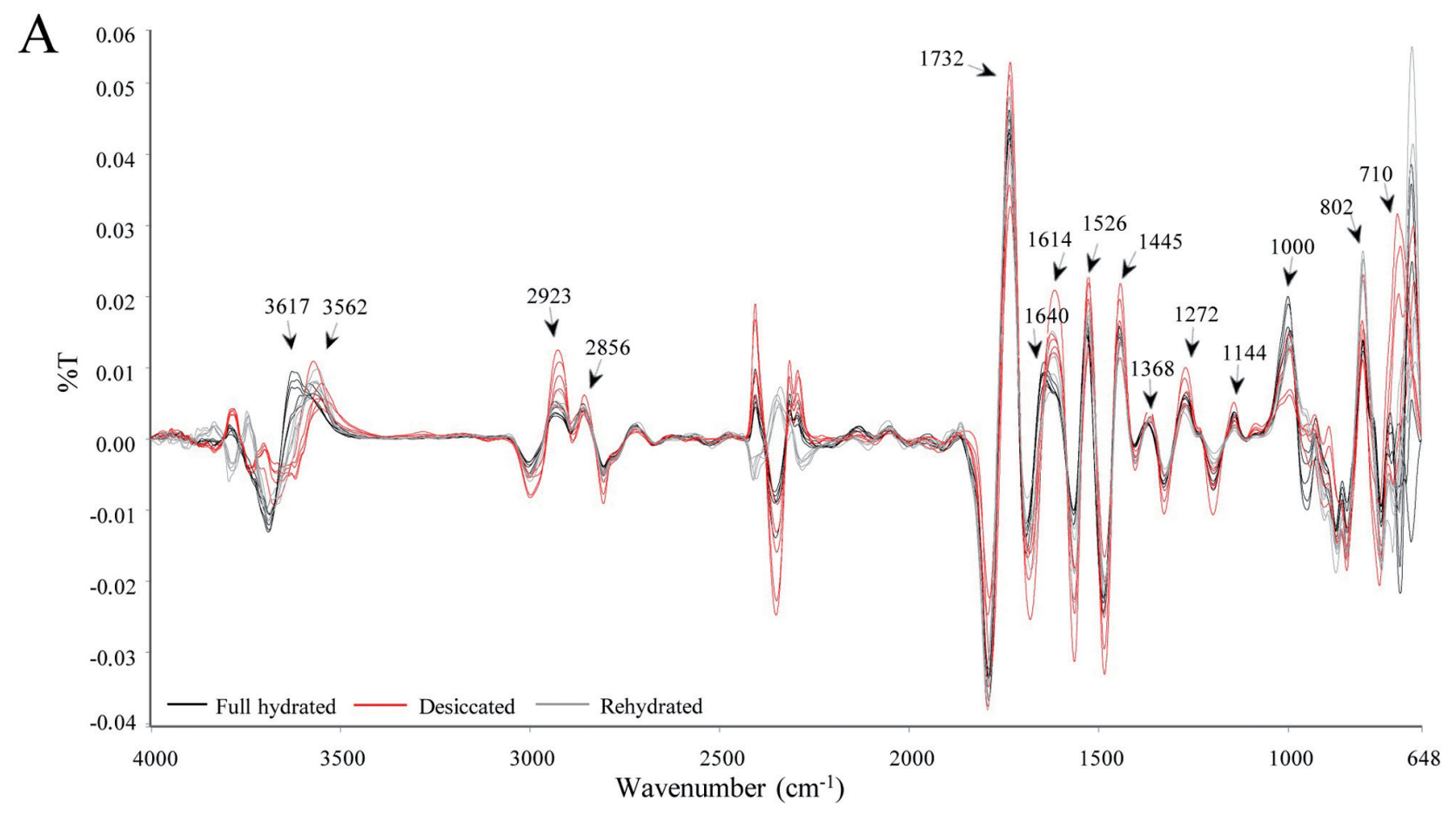

B
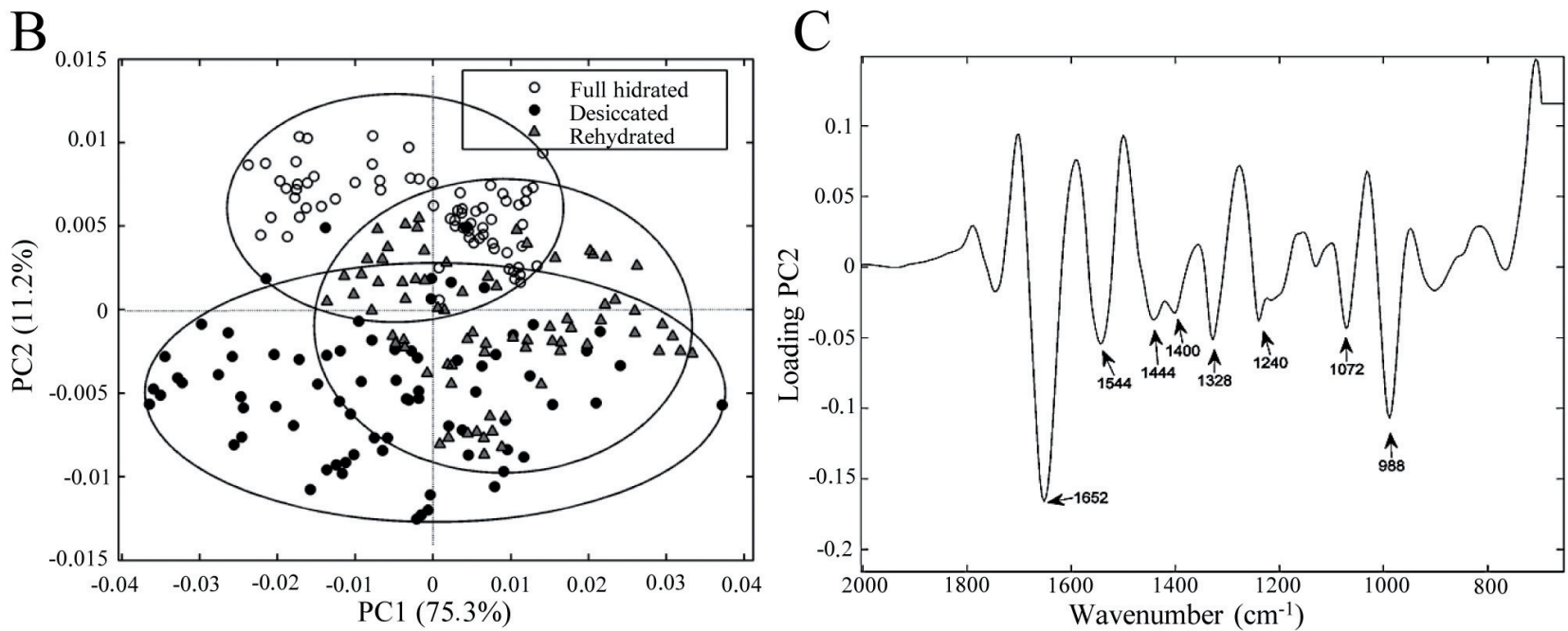

FIgURE 4. Chemical changes. A shows the mean spectra of five cells in full hydration, desiccation and rehydration, respectively. The most prominent peaks were indicated by their wavenumber on top. This illustration is representative of three independent experiments. $\mathrm{B}$ and $\mathrm{C}$ show PCA plots using the whole spectral range and reduced spectral range selecting the region with more prominent peaks, respectively.

Figura 4. Cambios químicos. A muestra los espectros promedio de 5 células en cada una de las condiciones de hidratación completa, desecación o rehidratación, respectivamente. En los picos más prominentes se indica el número de la longitud de onda. Esta ilustración es representativa de tres experimentos independientes. B y C muestran el análisis de componentes principales (ACP) usando el rango espectral completo y el rango seleccionado en el que se ubican los picos más prominentes, respectivamente. 


\section{DISCUSSION}

The rapid desiccation and recovery of $H$. dentatum indicated by the physiological parameters is consistent with recently published data (Garces Cea et al. 2014, Saldaña et al. 2013), and indicates that this filmy ferns behaves as a fully tolerant poikilohydric homoiochlorophyllaceous plant, precluding the induction of protective systems, suggesting a constitutive mechanism of cellular protection (Proctor 2003). To our knowledge the ability of this plant to recover throughout at least 3 cycles of desiccation and rehydration has not been previously reported, and is consistent with the short-term nature of alternating periods of humidity and shadow followed by periods of light and drought, occurring constantly in the trunks of rain forest, where this filmy fern lives.

In vivo morphological results showed that pronounced changes occurs in the anatomy of leaves and cells.

During desiccation, leaves and pinnae fold upward, since the adaxial side underwent negative strain to a greater extent than the abaxial side, resulting in the pinnae becoming highly concave (Layton et al. 2010). Leaf folding has been reported in other resurrection plants such as the angiosperms Harberlea rhodopensis (Georgieva et al. 2010), and Myrothamnus flabellifolius (Moore et al. 2006) and the fern Polypodium polypodioides (Layton et al. 2010), among others (Rascio \& La Rocca 2005). This strategy has been previously reported as a photo-protective system to prevent the absorption of excess light and accumulation of free radicals, since leaf folding minimizes light-chlorophyll interactions (Georgieva et al. 2010). Leaf folding upon desiccation and leaf extension upon rehydration were both fast events (20 min), suggesting that the resurrection mechanisms must be mostly related with reassembly and reactivation of components which has been conserved undamaged. Rehydrated fronds were not able to recover the light green color, characteristic of the unstressed fronds, which is consistent with the uncompleted recovery of photosynthesis rate.

At cellular level, the most visible result of desiccation was a considerable reduction of cell volume, that is consequence of a massive loss of water from the large central vacuole, which leads to its shrinkage and to a mobilization of the cell contents inward, so the cells result entirely contracted (Rascio \& La Rocca 2005). In fact, the chloroplasts were dragged toward the cell borders, and some of them are inactivated since their fluorescence was undetectable. The transient dislocation of chloroplasts has been previously reported in angiosperms (Vicre et al. 2004, Georgieva et al. 2010) and in mosses (Proctor et al. 2007). Inactivation of chloroplasts during desiccation is consistent with the strategy of photo-protection system based on leaves folding commented above. During rehydration, chloroplasts become fluorescent rather quickly. This is in coherence with the physiological results, indicating that $H$. dentatum is a homoioclorophyllaceous resurrection plant.

The reduction of cell size is due almost entirely to an extensive folding of the cell wall (Vicre et al. 2004). Cell wall folding upon desiccation has been reported before in mosses and angiosperms (Proctor et al. 2007, Vicre et al. 2004, Moore et al. 2013). The reversible changes in cell wall architecture have been proposed as a mechanism for counteracting mechanical stress (Gechev et al. 2012), which is defined as the tension that develops between and within the plasma membrane and the cell wall to a loss of turgor pressure (Walters et al. 2002). Desiccation induced cell wall folding has been proposed to be essential for structural preservation of tissue and the extent and manner of such folding is species specific and dependent upon the chemical composition of the cell wall (Moore et al. 2006). More specifically, it has been indicated that changes in the cell wall polysaccharides and proteins occur during desiccation, making the cell wall more flexible, and enabling reversible folding of the leaves (Gechev et al. 2012).

In vivo chemical data show that the main differences in the chemical composition of desiccated cells compared with full hydrated and rehydrated cells were changes in secondary structure of proteins and changes in a cell wall polysaccharide, most likely arabinan (see Table I). Although previous research regarding changes of the cell wall that may occur in leaf tissues due to desiccation have been performed in few resurrection plants, expansins and dehydrins has been involved in effecting cell wall protection during desiccation and rehydration (Moore et al. 2013). No changes in the total amount of proteins were evident during desiccation and rehydration of $H$. dentatum tissues, which is consistent with previous reports (Garces Cea et al. 2014), but changes in the secondary structure were evidenced by the shifting of the band at $1640 \mathrm{~cm}^{-1}$ in rough spectra. Interestingly, exactly the same band was shown to be shifted during desiccation-induced conformational changes of a recombinant LEA (Late embryogenesis abundant) protein (Tolleter et al. 2007). Structurally considered to be random coil, LEA proteins have been shown to form stabilized structures in the vicinity of membranes and they can act as antiaggregants, protecting the proteomes against water loss induced aggregation (Moore et al. 2009). LEA are extremely hydrophilic proteins produced at high levels in seeds and pollen grains during the latter stages of maturation and desiccation that are ubiquitously produced by plants, algae and cyanobacteria in response to water stress (Rascio \& La Rocca 2005), where LEA proteins can reach as much as $40 \%$ of the dry weight in some resurrection plants (Gechev et al. 2012). It is very likely that changes in secondary structure of proteins demonstrated by FT-IR spectroscopy correspond to LEA proteins, nevertheless, further research must be done to specifically identify the proteins (and its conformational changes) involved in resurrection of $H$. dentatum. 
The second relevant difference between desiccated and full hydrated and rehydrated cells detected by chemical measurements was a change in the polysaccharide composition of the cell walls, related with the presence of pectin and arabinan (Table I). A study of the leaf cell wall composition of the woody resurrection plant Myrothamnus flabelifolia suggested that constitutive protection was afforded to the wall of this species through the presence of significant amounts of highly flexible pectin associated arabinans and arabinogalactan proteins (Moore et al. 2006). Besides, it has been shown that the resurrection fern Mohria caffrorum possesses a very different cell wall profile but interestingly utilize mainly arabinogalactan proteins (AGPs) as cell wall desiccation protectants (Moore et al. 2013). AGPs are believed to function in cell lubrication and have been proposed to act as cell wall plasticizers (Moore et al. 2006). The chemical definition of plasticizers involves their use as dispersants added to polymer blends to increase the plasticity and/or fluidity of a material. In the context of the cell walls the role of these substances (e.g. as loosening agents) has been indicated as key determinants in influencing plasticity and playing a role in response to osmotic stress (Moore et al. 2013). It also has been proposed that high concentration of arabinan polymers associated with the pectin matrix of the cell wall is likely to be one of the major components that allow the wall to desiccate and fold without any apparent damage (Moore et al. 2006). Arabinose polymers have been shown to be highly mobile and to have a high water absorbing capacity, properties ideally suited to cell wall rehydration (Moore et al. 2006).

Taken together, results showed that $H$. dentatum, in coherence with its poikilohydric life style, is a homoiochlorophyllous resurrection plant, fully tolerant to desiccation that manages the mechanical and oxidative stress by reducing the cell volume through the folding of the cell walls, which is a consequence of changes in secondary structure of proteins and in cell wall polysaccharides. The ability of cell walls to fold by changing their chemical nature is an adaptive strategy against desiccation that is essential for the survival of resurrection plants. These exceptional features become even more remarkable when compared to the rigidification of the cell wall in response to drought in non-resurrection plants (Rascio \& La Rocca 2005). Even when desiccation tolerance clearly is a complex phenomenon and research over the past few decades has reinforced the realization that multiple factor "act in concert" to effect protection (Moore et al. 2009), the data presented here highlights the role of cell wall folding, since it allows photo-protective folding of leaves and is itself a mechanism to withdraw mechanical stress, being a very important contribution to the much more extensive phenomenon of resurrection. It is important to emphasize that, to our knowledge, this is the first time that morphological and chemical changes occurring during desiccation and rehydration are studied in vivo, avoiding fixation or any other sample treatment.

The demand of water for agriculture is constantly increasing, and will continue to do so due to the rise in the human population and the effects of climate change on rainfall and evaporative demand in many regions of the world (Tardieu 2005). Consequently, in the last decades, researchers have directed their efforts towards the study of plants with improved water-use efficiency and increased resistance to water deficits, aiming to apply this knowledge to a biotechnological solution for crop plant improvement (Cruz De Carvalho et al. 2014). The resurrection plants are interesting not only because of the desiccation tolerance and as a source for gene discovery but also because they have unique metabolites, some of which have potential uses in biotechnology and medicine (Gechev et al. 2012). H. dentatum is an extreme case of resurrection plant, prepared for withdraws rapid severe and repetitive desiccation-induced stress trough constitutive systems of protection and reparation of cells and tissues that presented remarkable advantages as a model for the studying of desiccation tolerance, such as auto fluorescence of cellular compartments, fronds made of one cell layer and long survival of fronds under laboratory conditions, having the potential to open the way to exciting advances in understanding the biology of resurrection plants.

Although previous studies with Hymenophyllaceae species have shown valuable empirical evidence of an evolutionary shift of adaptive strategy from typical vascular plant adaptation to the poikilohydry most typical of bryophytes (Proctor et al. 2012, Parra et al. 2015), we are far from understanding the family or its diversity and Chile is one of the best places in the world to begin (Michael Proctor pers. comm.). The results presented here depicted how the cells of $H$. dentatum change its architecture and chemical composition highlighting the role of cell wall and protein content, in coherence with the general strategy of other Hymenophillaceae members, but having full tolerance to desiccation, which is not a typical trait of vascular plants. The understanding of the different strategies and molecular mechanisms of vascular plant that is fully tolerant to desiccation is not only important as a contribution to the basic knowledge of plant biology but also has the potential to be an interesting source of biotechnological solutions, so each species must be studied.

\section{ACKNOWLEDGEMENTS}

This work was supported by San Sebastian University, [Grant number DIUSS 2013-0022-I] and by Vegetal Biotechnology Center of Andrés Bello University. We thank to Katalapi Park and to CMA Bio Bio Microscopy Center. We also thank to "FONDECYT iniciación 11110505". 


\section{REFERENCES}

Ami, D., P. Mereghetti, A. Natalello \& S.M. Doglia. 2011. Fourier transform infrared microspectroscopy as a tool for embryonic stem cell studies. In: C. Atwood (ed.), Methodological advances in the culture, manipulation and utilization of embryonic stem cells for basic and practical applications, Chapter 11, pp. 193-218. InTech, Rijeka, Croatia.

Ami, D., A. Natalello, P. Mereghetti, T. Neri, M. Zanoni, M. Monti, S.M. Doglia \& C.A. Redi. 2010. FT-IR spectroscopy supported by PCA-LDA analysis for the study of embryonic stem cell differentiation. Spectroscopy 24: 89-97.

Barth, A. \& C. Zscherp. 2002. What vibrations tell us about proteins. Quarterly Reviews of Biophysics 35: 369-430.

Bewley, J.D. 1979. Physiological aspects of desiccation tolerance. Annual Review of Plant Physiology. 30: 195-238.

Bolha-NordenKampF, H.R. \& G. ÖQuist. 1993. Chlorophyll fluorescence as a tool in photosynthesis research. In: D.O. Hall, J.M. Scurlock, H.R. Bolhar-Nordenkampf, R.C. Leegood, S.P. Long, (eds.), Photosynthesis and production in a changing environment, Chapter 12, pp. 193-206. Springer, London, United Kingdom.

Cruz De Carvalho, R., A. Bernardes Da Silva, R. Soares, A.M. Almeida, A.V. Coelho, J. Marques Da Silva \& C. BRANQUINHO. 2014. Differential proteomics of dehydration and rehydration in bryophytes: evidence towards a common desiccation tolerance mechanism. Plant, Cell \& Environment 37: 1499-1515.

Ellis, J.R. \& R.M. LeECH. 1985. Cell size and chloroplast size in relation to chloroplast replication in light-grown wheat leaves. Planta 165: 120-125.

Farrant, J.M. \& J.P. Moore. 2011. Programming desiccationtolerance: from plants to seeds to resurrection plants. Current Opinion in Plant Biology 14: 340-345.

Garces Cea, M., S. Claverol, C. Alvear Castillo, C. Rabert Pinilla \& L. Bravo Ramirez. 2014. Desiccation tolerance of Hymenophyllaceae filmy ferns is mediated by constitutive and non-inducible cellular mechanisms. Comptes Rendus Biologies 337: 235-243.

Gechev, T.S., C. Dinakar, M. Benina, V. Toneva \& D. Bartels. 2012. Molecular mechanisms of desiccation tolerance in resurrection plants. Cellular and Molecular Life Sciences 69: 3175-3186.

Georgieva, K., E. Sarvari \& A. Keresztes. 2010. Protection of thylakoids against combined light and drought by a lumenal substance in the resurrection plant Haberlea rhodopensis. Annals of Botany 105: 117-126.

Hennequin, S. 2004. Le genre Hymenophyllum Sm. (Hymenophyllaceae, Filicopsida): systématique phylogénétique, évolution morphologique et histoire biogéographique. Université Pierre et Marie Curie, Paris. $266 \mathrm{pp}$.

Ivanova, D.G. \& B.R. Singh. 2003. Nondestructive FTIR monitoring of leaf senescence and elicitin-induced changes in plant leaves. Biopolymers 72: 79-85.

Kacuráková, M., P. Capek, V. Sasinková, N. Wellner \& A. EBringEROVÁ. 2000. FT-IR study of plant cell wall model compounds: pectic polysaccharides and hemicelluloses.
Carbohydrate Polymers 43: 195-203.

Konwar, M. \& G.D. Baruah. 2011. On the nature of vibrational bands in the FTIR spectra of medicinal plant leaves. Archives of Applied Science Research 3: 214-221.

Larsen, C., M. Ponce \& M. Scataglini. 2013. Revision of Hymenophyllum (Hymenophyllaceae) of Southern Argentina and Chile. Gayana Botánica 70: 274-329.

Layton, B.E., M.B. Boyd, M.S. Tripepi, B.M. Bitonti, M.N. Dollahon \& R.A. Balsamo. 2010. Dehydrationinduced expression of a $31-\mathrm{kDa}$ dehydrin in Polypodium polypodioides (Polypodiaceae) may enable large, reversible deformation of cell walls. American Journal of Botany 97: 535-544.

Lichtenthaler, H.K. 1988. In vivo chlorophyll Fluorescence as a tool for stress detection in plants. In: H.K. Lichtenthaler (ed.), Applications of Chlorophyll Fluorescene in Photosynthesis Research, Stress Physiology, Hydrobiology and Remote Sensing, Chapter 2, pp. 129-142, Kluwer Academic Publishers, Dordrecht, Netherlands .

Mazurek, S., A. Mucciolo, B.M. Humbel \& C. Nawrath. 2013. Transmission Fourier transform infrared microspectroscopy allows simultaneous assessment of cutin and cell-wall polysaccharides of Arabidopsis petals. The Plant Journal 74: 880-891.

McCann, M.C., M. Hammouri, R. Wilson, P. Belton \& K. Roberts. 1992. Fourier transform infrared microspectroscopy is a new way to look at plant cell walls. Plant Physiology 100: 1940-1947.

Moore, J.P., N.T. Le, W.F. Brandt, A. Driouich \& J.M. Farrant. 2009. Towards a systems-based understanding of plant desiccation tolerance. Trends in Plant Science 14: 110-117.

Moore, J.P., E. Nguema-Ona, L. Chevalier, G.G. Lindsey, W.F. Brandt, P. Lerouge, J.M. Farrant \& A. Driouich. 2006. Response of the leaf cell wall to desiccation in the resurrection plant Myrothamnus flabellifolius. Plant Physiology 141: 651-662.

Moore, J.P., E.E. Nguema-Ona, M. Vicre-Gibouin, I. Sorensen, W.G. Willats, A. Driouich \& J.M. Farrant. 2013. Arabinose-rich polymers as an evolutionary strategy to plasticize resurrection plant cell walls against desiccation. Planta 237: 739-754.

Noguchi, T. 2008. FTIR detection of water reactions in the oxygen-evolving centre of photosystem II. Philosophical transactions of the Royal Society of London. Series B 363: 1189-1195.

Oliver, M.J., J. Velten \& B.D. Mishler. 2005. Desiccation tolerance in bryophytes: a reflection of the primitive strategy for plant survival in dehydrating habitats? Integrative and Comparative Biology 45: 788-799.

Oliver, M.J., A.J. Wood \& P. O’Mahony. 1997. How some plants recover from vegetative desiccation: A repair based strategy. Acta Physiologiae Plantarum 19: 419-425.

Omasa, K., A. Konishi, H. Tamura \& F. Hosor. 2009. 3D confocal laser scanning microscopy for the analysis of chlorophyll fluorescence parameters of chloroplasts in intact leaf tissues. Plant and Cell Physiology 50: 90-105.

Parra, M., K. Acuña, L. Corcuera \& A. Saldaña. 2009. Vertical distribution of Hymenophyllaceae species among host tree microhabitats in a temperate rain forest in Southern Chile. Journal of Vegetation Science 20: 588-595. 
Parra, M., K. Acuña, A. Sierra Almeida, C. Sanfuentes, A. Saldaña, L. Corcuera \& L. Bravo. 2015. Photosynthetic Light Responses May Explain Vertical Distribution of Hymenophyllaceae Species in a Temperate Rainforest of Southern Chile. PLoS ONE 10(2): e0145475

Proctor, M.C. 2003. Comparative ecophysiological measurements on the light responses, water relations and desiccation tolerance of the filmy ferns Hymenophyllum wilsonii Hook. and H. tunbrigense (L.) Smith. Annals of Botany 91: 717-27.

Proctor, M.C. 2012. Light and desiccation responses of some Hymenophyllaceae (filmy ferns) from Trinidad, Venezuela and New Zealand: poikilohydry in a lightlimited but low evaporation ecological niche. Annals of Botany 109: 1019-26.

Proctor, M.C., R. Ligrone \& J.G. Duckett. 2007. Desiccation tolerance in the moss Polytrichum formosum: physiological and fine-structural changes during desiccation and recovery. Annals of Botany 99: 75-93.

Proctor, M.C. \& Z. TuBA. 2002. Poikilohydry and homoiohydry: antithesis or spectrum of possibilities? New Phytologist 156: 327-349.

Pryer, K.M., A.R. Smith \& J.E. Skog. 1995. Phylogenetic relationships of extant ferns based on evidence from morphology and rbcL sequences. American Fern Journal 85: 205-282.

Rascio, N. \& N. La Rocca. 2005. Resurrection plants: The puzzle of surviving extreme vegetative desiccation Critical Reviews in Plant Sciences 24: 209-225.

Rodriguez, M.C., D. Edsgard, S.S. Hussain, D. Alquezar, M. Rasmussen, T. Gilbert, B.H. Nielsen, D. Bartels \& J. Mundy. 2010. Transcriptomes of the desiccation-tolerant resurrection plant Craterostigma plantagineum. The Plant Journal 63: 212-28.

Saldaña, A., J.M. Parra, A. Flores-Bavestrello, L.J. Corcuera \& L. Bravo. 2013. Effects of forest successional status on microenvironmental conditions, diversity, and distribution of filmy fern species in a temperate rainforest. Plant Species Biology 29: 253-262.

Schreiber, U. \& W. Bilger. 1993. Progress in chlorophyll fluorescence research: Major developments during the past years in retrospect. In: H.D. Behnke, U. Lüttge, K. Esser, J. Kadereit \& M. Runge (eds), Progress in Botany, Vol 54, pp. 151-173, Springer Berlin Heidelberg, Germany.

Schreiber, U., W. Bilger \& C. Neubauer. 1995. Chlorophyll fluorescence as a nonintrusive indicator for rapid assessment of in vivo photosynthesis. In: E. Schulze \& M. Caldwell (eds), Ecophysiology of Photosynthesis, Vol 100, pp. 49-70, Springer Study Edition, Heidelberg, Germany .

Stehfest, K., J. Toepel \& C. Wilhelm. 2005. The application of micro-FTIR spectroscopy to analyze nutrient stress-related changes in biomass composition of phytoplankton algae. Plant Physiology and Biochemistry 43: 717-726.

TARDIEU, F. 2005. Plant tolerance to water deficit: physical limits and possibilities for progress. Comptes Rendus Geoscience 337: $57-67$.

Tolleter, D., M. Jaquinod, C. Mangavel, C. Passirani, P. Saulnier, S. Manon, E. Teyssier, N. Payet, M. H. Avelange-Macherel \& D. Macherel. 2007. Structure and function of a mitochondrial late embryogenesis abundant protein are revealed by desiccation. Plant Cell 19: 15801589.

Vicre, M., O. Lerouxel, J. Farrant, P. Lerouge \& A. Driouich. 2004. Composition and desiccation-induced alterations of the cell wall in the resurrection plant Craterostigma wilmsii. Physiologia Plantarum 120: 229-239.

Walters, C., J. Farrant, N.W. Pammenter \& P. BerJak. 2002. Desiccation stress and damage. In: M. Black \& H.W. Pritchard (eds), Desiccation and survival in plants: Drying without dying, Chapter 9, pp. 263-282. Wallington, United Kingdom

WANG, Y. 2012. Application of fourier transform infrared microspectroscopy (FTIR) and thermogravimetric analysis (TGA) for quick identification of Chinese herb Solanum lyratum. Plant Omics 5: 508-513.

Willigen, C.V., N.W. Pammenter, S.G. Mundree \& J. Farrant. 2004. Mechanical stabilization of desiccated vegetative tissues of the resurrection grass Eragrostis nindensis: does a TIP 3; 1 and/or compartmentalization of subcellular components and metabolites play a role? Journal of Experimental Botany 55: 651-661.

Wolkers, W. \& F. Hoekstra. 2003. In situ FTIR assessment of desiccation-tolerant tissues. Spectroscopy 17: 297-313.

YANG, J. \& H.E. Yen. 2002. Early salt stress effects on the changes in chemical composition in leaves of ice plant and Arabidopsis. A Fourier transform infrared spectroscopy study. Plant Physiology 130: 1032-42.

Zeier, J., L. Schreiber. 1999. Fourier transform infraredspectroscopic characterization of isolated endodermal cell walls from plant roots: chemical nature in relation to anatomical development. Planta 209: 537-42.

Recibido: 28.07 .15

Aceptado: 29.08.16 